How to cite this article:

Kamaruddin, M. I. H., \& Auzair, S. M. (2020). Accountability in Malaysian Islamic social enterprises (ISEs): Stakeholder versus management perspectives. International Journal of Banking and Finance, 15(2), 47-64. https://doi.org/10.32890/ijbf2020.15.2.3

\title{
Accountability in Malaysian Islamic Social Enterprises (ISEs): Stakeholder versus Management Perspectives
}

\author{
${ }^{1}$ Muhammad Iqmal Hisham Kamaruddin \\ Faculty of Economics and Muamalat, \\ Universiti Sains Islam Malaysia, Malaysia \\ ${ }^{2}$ Sofiah Md Auzair \\ Faculty of Economics and Management, \\ Universiti Kebangsaan Malaysia, Malaysia \\ ${ }^{1}$ Corresponding author:m.iqmalhisham@gmail.com; \\ ${ }^{2}$ sofiah@ukm.edu.my
}

\section{A R T I C L E I N F O}

Article history:

Received 3 November 2019

Revised form 18 January 2020

Accepted 31 January 2020

Published 31 July 2020

JEL Code: E 16, L 14, M 41,

O 53, P 31, Z 12

Keywords:

Accountability, Islamic accountability, Islamic social enterprise (ISE), stakeholder perspective, management perspective.
A B S T R A C T

This study compares stakeholder and management perspectives on accountability practices in Malaysian Islamic Social Enterprises (ISEs). Two sets of questionnaires were used in the survey for this study. The first set was answered randomly by 100 ISE stakeholders, and the second set was answered by the management from 102 Malaysian ISEs. The findings showed that both ISE stakeholders and ISE management have mixed agreement for all six proposed accountability dimensions. Based on this result, Malaysian ISEs need to improve their accountability practices, particularly with regard to input, output and procedures. The accountability measurement proposed in this study could also be used by other ISEs as indicators to evaluate their accountability practices. 


\section{Introduction}

The conflict between stakeholders and management of an organisation has long been a topic of debate. Based on agency, stewardship and stakeholder theories, this issue is derived primarily from the accountability relationship between the stakeholders and management where there is continuous demand and supply of information founded on the responsibilities of the stakeholders (principal) assigned to the management (agent). The management is responsible for their mandate and accountable for all their actions and activities.

This accountability relationship emerged with the agency theory. Previous studies on accountability found that the relationship between the principal and agent were opposed to each other in determining the direction of the organisation. Later, due to development and the growing population covered by the organisation, scholars shifted focus to the stakeholder theory in order to recognise other interest groups or multiple relationships, especially in nonprofit organisations (Ebrahim, 2003). These relationships became more complex with the introduction of the concepts of social enterprise (SE) and Islamic social enterprise (ISE). In this case, a combination of social and economic objectives has increased the number of SE/ISE stakeholders due to increased participation from various interest groups. This change comes with additional tension because of the different interests of the various groups of stakeholders either among themselves or with the management (Ebrahim, Battilana \& Mair, 2014).

Despite constructive studies and discussions on accountability in SE (Ebrahim et al., 2014; Izaguirre, 2015; Sarman, Zainon, Atan, Bakar, Yoke, Ahmad $\&$ Shaari, 2015), there are limited studies and discussions on accountability in the ISE context. Studies on ISEs are more focused on development concepts (Hati \& Idris, 2014; Mohiuddin, 2017; Muhamed, Kamaruddin \& Nasrudin 2018), sustainability (Abdul Kadir \& Mhd Sarif, 2015); governance (Muhamed, Ramli, Shukor \& Kamaruddin, 2016), financial management (Ramli, Muhamed \& Kamaruddin, 2016) and classification (Kamaruddin \& Auzair, 2018). Therefore, this has prompted this study to examine ISE accountability from both the stakeholder and management perspectives.

\section{Literature Review}

To date, there is no specific registration, organisational classification, legal standard nor specific authority for SE and ISE in Malaysia. Therefore, any nonprofit organisation in Malaysia adopting the SE concept, which is a combination of both social and economic activities in an organisation, is recognised as SE. In addition, there is no specific authorised database or sources of SE in Malaysia (Zainon et al., 2014). Furthermore, there is no authority responsible for SE and ISE registration and monitoring in Malaysia. As a result, there have been limited studies conducted on SE and ISE in Malaysia. 
For instance, Sarman et al. (2015) used the Social Enterprise Alliance (SEA) database developed by public initiatives which is still limited to only about 30 SEs in Malaysia registered in this database. This database is incomplete, and there are no specific characteristics for identifying SEs. Meanwhile, Kamaruddin and Auzair (2018) classified ISE in Malaysia from their economic sectors whether in public, private or non-profit based on their legal establishment.

ISE could adopt a similar definition of SE, but it has to be distinguished by additional Islamic practices. Islamic organisations like ISE should have Islamic values such as worship or obedience to Allah and operate based on Islamic teachings or shariah principles as stated by Ahmad (1988). Therefore, it can be concluded that ISE is an entity which is driven by both social and business objectives according to Islamic principles and values (Kamaruddin \& Auzair, 2019b).

As SE and ISE are driven primarily by social objectives, most researchers agreed that SE and ISE are classified as part of the non-profit sector (Defourny \& Nyssens, 2008). In Malaysia, non-profit organisations include societies, associations, foundations and companies limited by guarantee (CLBG). Each of these non-profit organisations is bound to specific legislations such as the Trustee (Incorporation) Act 1952, Companies Act 2016, Societies Act 1966 or States Enactment. Therefore, it is believed that any non-profit organisation in Malaysia that aligns with the objectives of ISE can be recognised as ISE.

Meanwhile, defining ISE accountability indicators is complex and challenging. As ISEs involve large groups of stakeholders compared to other nonprofit organisations, any decision and action performed by an ISE affects these groups of stakeholders (Hyndman \& McMahon, 2011). Besides, as an Islamic organisation, ISE accountability must also encompass Islamic accountability dimensions in addition to existing conventional accountability dimensions. This includes Islamic social objectives, Islamic economic objectives and other Islamic principles and values (Kamaruddin \& Auzair, 2019a; 2018).

Ebrahim et al. (2014) stressed that the problem of multiple accountabilities faced by ISEs is how to align the interests of various stakeholders, and whose interests to prioritise when those interests conflict. Besides, conflicts between social and economic performance indicators in ISE due to a combination of social and economic objectives add tension, especially concerning accountability (Cheah, Amran, \& Yahya, 2019). Moreover, ISEs tend to have poor financial management practices due to a lack of financial knowledge. This limits their ability to secure financing and expand their economic activities (Hynes, 2009).

ISEs are responsible not only for the social needs of various groups of stakeholders, but are required to balance this response with economic needs. Moreover, ISEs normally focus on upward accountability (such as funders and government) and ignore full accountability with downward accountability (such as beneficiaries) (O’Dwyer \& Unerman, 2008). Where different groups of stakeholders' interests come into conflict, there is a need for ISEs to bring these interests into an optimal balance to ensure fairness and equity among the 
stakeholders, as suggested in the ethical model of stakeholder theory (Dhanani \& Connolly, 2012). This 'balance' action is needed based on the belief that an organisation has accountabilities and responsibilities to all those whose life experiences may be affected by the organisation's decisions (Cooper \& Owen, 2007). It is a difficult task as stakeholders often have goals which are sometimes contrary to ISE goals (Wronka-Pospiech, 2016), whereas accountability from the perspective of stakeholder theory is ensuring responsibility to all stakeholders (Yuesti, Novitasari, \& Rustiarini, 2016).

Therefore, in an attempt to identify suitable ISE accountability indicators, accountability dimensions must be viewed to concern all possible ISE stakeholders and management interests. In this case, Candler and Dumont (2010) proposed three accountability dimensions which consist of accountability for input, output and procedures as the best measurement to indicate, multiple accountability. Under accountability for input, four indicators are suggested which include fund collection, income generation, volunteer resources and brand name (reputation capital). Meanwhile, under accountability for output dimension, several indicators are proposed by focusing on goods and services delivered by ISE, the impact of these goods and services on stakeholders and also its capabilities to achieve both social and economic objectives. Whereas, under accountability for the procedural dimension, the accountability indicators consist of: laws and regulations, mission and vision, ethical and legitimacy aspects.

However, depending on these accountability dimensions alone is insufficient without additional Islamic accountability dimensions. Muhamed et al. (2018) stated that ISEs differ from social enterprises (SE) where ISEs must have Islamic objectives apart from conventional social and economic objectives. This is because Islamic objectives known as maqasid shariah, is a vital foundation for every Islamic organisation. In addition, ISEs should embed Islamic practices in their daily operations. Islamic values such as worshipping or obedience to Allah and operating based on Islamic teachings, known as shariah principles, as stated by Ahmad (1988), are supposedly embedded within ISEs. In this case, another three accountability dimensions derived from the Islamic perspective are proposed as part of the ISE accountability indicators. These include accountability for Islamic social objectives, Islamic economic objectives and other Islamic principles and values (Kamaruddin \& Auzair, 2019a, 2019b).

Based on the above discussion, this study examines ISE accountability practices from the stakeholder and management perspectives in order to gain a better understanding for Malaysian ISEs so as to discharge their accountability. Specifically, this study attempts to answer the following research questions:

1. Do Malaysian ISEs comply with accountability practices from the stakeholders' perspective?

2. What are the most significant accepted accountability practices from the ISE management's perspective? 
3. Does stakeholder perception of the accountability practices of ISEs differ significantly from the perceived importance of ISE management?

\section{Methodology}

This study utilised a survey to collect the required data. Two questionnaires; one for ISE stakeholders and another for ISE management were developed by focusing on accountability in Malaysian ISEs. Based on the literature on accountability for ISEs, this study proposed six accountability dimensions to be tested in order to examine accountability practices in Malaysian ISEs, which were: (i) accountability for input; (ii) accountability for output; (iii) accountability for procedures; (iv) accountability for Islamic social objectives; (v) accountability for Islamic economic objectives; and (vi) accountability for other Islamic principles and values (Candler \& Dumont, 2010; Kamaruddin \& Auzair, 2019a; 2019b; Muhamed et al., 2018). There was a total of 25 items for these six accountability dimensions. Each item was tested using a five-point Likert-scale where respondents were asked to indicate the level of agreement for each accountability item with ' 1 ' for an item that is highly disagreeable and ' 5 ' for an item that is highly agreeable.

For ISE stakeholders, an open survey via Google Form was selected as a medium of data collection and all respondents involved with ISEs regardless of their type of involvement were encouraged to answer the questions. Using a 95 percent confidence level and a 10 percent margin of error in calculating the sample size (Sekaran \& Bougie, 2016), 96 respondents were required as a minimum sample size from the total Malaysian Muslim population in Malaysia which was 19.42 million (Department of Statistics Malaysia [DOSM], 2016). In this case, a total of 100 respondents were received.

Meanwhile, for the ISE management group, companies limited by guarantee (CLBG) with additional criteria such as adopting Islamic objectives and involvement with Islamic charity funds were identified as samples for this study. As of 31 December 2018, there are 2,040 registered CLBGs in Malaysia. After filtering, some 301 CLBGs consisting of 73 CLBGs with the name 'Berhad' and 228 CLBGs without the name 'Berhad' were identified as a suitable sample size for this study. For this cohort, a mail questionnaire approach was chosen by posting the questionnaire to the selected 301 Malaysian ISEs. 105 questionnaires $(34.88 \%)$ were returned and after cleaning the data, only 102 questionnaires were deemed useable for analysis.

For data analysis, this study employed descriptive statistics and independent t-test analysis using the Statistical Package for Social Sciences (SPSS) software in identifying ISE accountability practices from the perspectives of ISE stakeholders and ISE management. Detailed information on both ISE stakeholders and ISE management respondents are shown in Tables 1 and 2. 
Table 1. Information Profile of ISE Stakeholders

\begin{tabular}{|c|c|}
\hline Details & $\mathbf{N}=\mathbf{1 0 0}$ \\
\hline \multicolumn{2}{|l|}{ Demographic: } \\
\hline North region (Perlis, Kedah, Penang \& Perak) & 15 \\
\hline South region (Negeri Sembilan, Melaka \& Johor) & 36 \\
\hline East region (Kelantan, Terengganu \& Pahang) & 9 \\
\hline Central region (Selangor, Kuala Lumpur \& Putrajaya) & 36 \\
\hline Sabah \& Sarawak & 4 \\
\hline \multicolumn{2}{|l|}{ Gender: } \\
\hline Male & 49 \\
\hline Female & 51 \\
\hline \multicolumn{2}{|l|}{ Age: } \\
\hline Below 20 years old & 3 \\
\hline $21-40$ years old & 91 \\
\hline $41-60$ years old & 5 \\
\hline 61 years old and above & 1 \\
\hline \multicolumn{2}{|l|}{ Highest degree of education: } \\
\hline MCE/SPM & 4 \\
\hline Diploma/A Level & 9 \\
\hline Degree & 48 \\
\hline Master/PhD & 39 \\
\hline \multicolumn{2}{|l|}{ Profession: } \\
\hline Government employee & 17 \\
\hline Private employee & 26 \\
\hline Self-employed & 10 \\
\hline Housewife & 5 \\
\hline Student & 41 \\
\hline \multicolumn{2}{|l|}{ Income: } \\
\hline Less than RM1,000 & 30 \\
\hline RM1,000 - RM2,000 & 21 \\
\hline RM2,001 - RM4,000 & 27 \\
\hline RM4,001 - RM6,000 & 8 \\
\hline RM6,001 - RM8,000 & 7 \\
\hline More than RM8,000 & 7 \\
\hline \multicolumn{2}{|l|}{ Involvement with Malaysian ISEs: } \\
\hline Regulator/Government (upward accountability) & 7 \\
\hline Donor/Contributor (upward accountability) & 40 \\
\hline Activist/Volunteer/Member (inward accountability) & 44 \\
\hline Staff/Adviser (inward accountability) & 9 \\
\hline Partner/Ally (downward accountability) & 3 \\
\hline Beneficiary/Client (downward accountability) & 15 \\
\hline Media/Public Follower (horizontal accountability) & 42 \\
\hline
\end{tabular}


Table 2. Information Profile of ISE Management

\begin{tabular}{|c|c|}
\hline Details & $\mathbf{N}=\mathbf{1 0 2}$ \\
\hline \multicolumn{2}{|l|}{ Core Business: } \\
\hline Education \& training & 52 \\
\hline Service & 22 \\
\hline Manufacturing \& trading & 14 \\
\hline Health & 7 \\
\hline Investment $\&$ asset & 5 \\
\hline Others & 2 \\
\hline \multicolumn{2}{|l|}{ Years of Operation: } \\
\hline$<5$ Years & 38 \\
\hline $5-10$ Years & 28 \\
\hline $11-15$ years & 12 \\
\hline $16-20$ Years & 7 \\
\hline$>20$ Years & 17 \\
\hline \multicolumn{2}{|l|}{ Nature of Activity: } \\
\hline Social and economic activities conducted separately within an entity & 26 \\
\hline Social and economic activities conducted as separate entities & 22 \\
\hline $\begin{array}{l}\text { Social and economic activities are conducted together/embedded within } \\
\text { an entity }\end{array}$ & 54 \\
\hline \multicolumn{2}{|l|}{ Financial Resource Nature: } \\
\hline Fully funded & 42 \\
\hline Partially funded & 33 \\
\hline Self-sustained & 27 \\
\hline \multicolumn{2}{|l|}{ Social Activity Level: } \\
\hline District & 17 \\
\hline State & 14 \\
\hline Region & 10 \\
\hline National & 31 \\
\hline International & 29 \\
\hline \multicolumn{2}{|l|}{ Economic Activity Level: } \\
\hline District & 21 \\
\hline State & 17 \\
\hline Region & 12 \\
\hline National & 30 \\
\hline International & 21 \\
\hline
\end{tabular}




\section{Analysis of Results}

This study proposed six accountability dimensions: (i) accountability for input; (ii) accountability for output; (iii) accountability for procedures; (iv) accountability for Islamic social objectives; (v) accountability for Islamic economic objectives; and (vi) accountability for other Islamic principles and values (Candler \& Dumont, 2010; Kamaruddin \& Auzair, 2019a, 2019b). ISE stakeholders and ISE management were required to state their level of agreement on accountability measurements based on these six accountability dimensions.

\subsection{Accountability for Input}

Accountability for input comprised four indicators as suggested by Candler and Dumont (2010) which are: (i) fund collection; (ii) income generation; (iii) volunteer resources; and (iv) brand name. Based on Table 3, 72.95 percent of ISE stakeholders and 86.4 percent of ISE management agreed that Malaysian ISEs complied with accountability practices for input. Among these four indicators, the most significant indicator agreed by ISE stakeholders was volunteer resources (75.4\%), followed closely by fund collection (74.2\%), brand name (72.2\%) and income generation (70\%). On the other hand, the most significant indicator agreed by ISE management was fund collection $(88.4 \%)$, followed closely by income generation $(87.8 \%)$, brand name $(87.6 \%)$ and volunteer resources $(81.8 \%)$. This result was probably due to ISE stakeholders prioritising their workforce impact rather than monetary impact, whereas ISE management was mostly concerned with the use of financial resources as an accountability issue. Regardless of the differences in priorities, all four indicators were accepted by the majority of ISE stakeholders and ISE management as accountability practices for input in Malaysian ISEs.

Table 3. Accountability for Input

\begin{tabular}{|c|c|c|c|c|}
\hline \multirow[t]{2}{*}{ Indicator } & \multicolumn{2}{|c|}{$\begin{array}{l}\text { ISE Stakeholder } \\
\text { Perspective } \\
(\mathrm{n}=100)\end{array}$} & \multicolumn{2}{|c|}{$\begin{array}{c}\text { ISE Management } \\
\text { Perspective } \\
(\mathrm{n}=102)\end{array}$} \\
\hline & Mean & $\%$ & Mean & $\%$ \\
\hline Fund collection & 3.71 & 74.2 & 4.42 & 88.4 \\
\hline Income generation & 3.50 & 70.0 & 4.39 & 87.8 \\
\hline Volunteer resources & 3.77 & 75.4 & 4.09 & 81.8 \\
\hline Brand name (reputational capital) & 3.61 & 72.2 & 4.38 & 87.6 \\
\hline Overall Mean & 3.65 & 72.95 & 4.32 & 86.4 \\
\hline
\end{tabular}




\subsection{Accountability for Output}

Accountability for output comprises three indicators according to Candler and Dumont (2010), which are goods and services, social capital and policy impact. These indicators were tested separately for the social and economic activities conducted on Malaysian ISEs, which comprised a total of six indicators as follows: (i) goods and services on social activities; (ii) goods and services on economic activities; (iii) impact of goods and services on social activities toward stakeholders; (iv) impact of goods and services on economic activities toward stakeholders; (v) achieving social objectives from goods and services delivered; and (vi) achieving economic objectives from goods and services delivered. Based on Table 4, 73.03 percent of ISE stakeholders and 86.97 percent of ISE management agreed that Malaysian ISEs complied with accountability practices for output.

Table 4. Accountability for Output

\begin{tabular}{|c|c|c|c|c|}
\hline \multirow[t]{2}{*}{ Indicator } & \multicolumn{2}{|c|}{$\begin{array}{l}\text { ISE Stakeholder } \\
\text { Perspective } \\
(\mathrm{n}=100)\end{array}$} & \multicolumn{2}{|c|}{$\begin{array}{c}\text { ISE Management } \\
\text { Perspective } \\
(n=102)\end{array}$} \\
\hline & Mean & $\%$ & Mean & $\%$ \\
\hline Goods and services on social activities & 3.70 & 74.0 & 4.42 & 88.4 \\
\hline $\begin{array}{l}\text { Goods and services on economic } \\
\text { activities }\end{array}$ & 3.67 & 73.4 & 4.36 & 87.2 \\
\hline $\begin{array}{l}\text { Impact of goods and services on social } \\
\text { activities toward stakeholders }\end{array}$ & 3.71 & 74.2 & 4.32 & 86.4 \\
\hline $\begin{array}{l}\text { Impact of goods and services on economic } \\
\text { activities toward stakeholders }\end{array}$ & 3.65 & 73.0 & 4.3 & 86.0 \\
\hline $\begin{array}{l}\text { Achieving social objectives from goods } \\
\text { and services delivered }\end{array}$ & 3.63 & 72.6 & 4.36 & 87.2 \\
\hline $\begin{array}{l}\text { Achieving economic objectives from } \\
\text { goods and services delivered }\end{array}$ & 3.55 & 71.0 & 4.33 & 86.6 \\
\hline Overall Mean & 3.65 & 73.03 & 4.35 & 86.97 \\
\hline
\end{tabular}

Among these six indicators, the most significant indicator agreed by ISE stakeholders was the impact of goods and services on social activities $(74.2 \%)$, followed closely by goods and services on social activities (74\%), goods and services on economic activities (73.4\%), impact of goods and services on 
economic activities toward stakeholders (73\%), achieving social objectives from goods and services delivered (72.6\%) and achieving economic objectives from goods and services delivered (71\%). The most significant indicator agreed by the ISE management was goods and services on social activities $(88.4 \%)$, followed by goods and services on economic activities and achieving social objectives from goods and services delivered (87.2\%), achieving economic objectives from goods and services delivered $(86.6 \%)$, impact of goods and services on social activities toward stakeholders $(86.4 \%)$ and the impact of goods and services on economic activities toward stakeholders $(86 \%)$. These results showed that both ISE stakeholders and ISE management were more focused on social activities output as compared to economic activities. Therefore, it can be concluded that all six indicators were accepted by the majority of ISE stakeholders and ISE management as accountability practices for output in Malaysian ISEs.

\subsection{Accountability for Procedures}

Accountability for procedures comprises four indicators as suggested by Candler and Dumont (2010) which are: (i) laws and regulations; (ii) mission and vision; (iii) ethical aspect; and (iv) legitimacy aspect. Based on Table 5, 81.85 percent of ISE stakeholders and 87.85 percent of ISE management agreed that Malaysian ISEs complied with accountability practices for procedures.

Table 5. Accountability for Procedures

\begin{tabular}{lcccc}
\hline \multicolumn{1}{c}{ Indicator } & \multicolumn{2}{c}{$\begin{array}{c}\text { ISE Stakeholder } \\
\text { Perspective } \\
(\mathrm{n}=100)\end{array}$} & \multicolumn{2}{c}{$\begin{array}{c}\text { ISE Management } \\
\text { Perspective } \\
(\mathrm{n}=102)\end{array}$} \\
\hline Laws and regulations & 4.13 & 82.6 & 4.41 & 88.2 \\
Mission and vision & 4.17 & 83.4 & 4.42 & 88.4 \\
Ethical aspect & 4.23 & 84.6 & 4.44 & 88.8 \\
Legitimacy aspect & 3.84 & 76.8 & 4.3 & 86.0 \\
\multicolumn{1}{c}{ Overall Mean } & 4.09 & 81.85 & 4.39 & 87.85 \\
\hline
\end{tabular}

Among these four indicators, the most significant indicator agreed by ISE stakeholders was ethical aspect $(84.6 \%)$, followed closely by mission and vision (83.4\%), laws and regulations (82.6\%) and legitimacy aspect (76.8\%). Similarly, the most significant indicator in accountability practices for procedures agreed 
by ISE management was ethical aspect $(88.8 \%)$, followed closely by mission and vision $(88.4 \%)$, laws and regulations $(88.2 \%)$ and legitimacy aspect $(86 \%)$. This result indicated that ethics was the top priority under accountability practices for procedures by both ISE stakeholders and ISE management. Therefore, it can be concluded that all four indicators were accepted by the majority of ISE stakeholders and ISE management as accountability practices for procedures in Malaysian ISEs.

\subsection{Accountability for Islamic Social Objectives}

Accountability for Islamic social objectives comprises four indicators based on the review of literature mentioned, which are: (i) ta'awanu alal birri wattaqwa (Islamic cooperation); (ii) amar ma'ruf nahi munkar (commanding the good and forbidding the evil); (iii) fastabiqul khairat (competitive in doing good deeds); and (iv) maslahah ummah (public interest) (Kamaruddin \& Auzair, 2019a, 2019b). Based on Table 6, 85.45 percent of ISE stakeholders and 83.95 percent of ISE management agreed that Malaysian ISEs complied with accountability practices for Islamic social objectives.

Table 6. Accountability for Islamic Social Objectives

\begin{tabular}{|c|c|c|c|c|}
\hline \multirow[t]{2}{*}{ Indicator } & \multicolumn{2}{|c|}{$\begin{array}{l}\text { ISE Stakeholder } \\
\text { Perspective } \\
(n=100)\end{array}$} & \multicolumn{2}{|c|}{$\begin{array}{l}\text { ISE Management } \\
\text { Perspective } \\
(\mathrm{n}=102)\end{array}$} \\
\hline & Mean & $\%$ & Mean & $\%$ \\
\hline $\begin{array}{l}\text { Ta'awanu alal birri wattaqwa (Islamic } \\
\text { cooperation) }\end{array}$ & 4.27 & 85.4 & 4.45 & 89.0 \\
\hline $\begin{array}{l}\text { Amar ma'ruf nahi munkar } \\
\text { (commanding the good and forbidding } \\
\text { the evil) }\end{array}$ & 4.25 & 85.0 & 4.36 & 87.2 \\
\hline $\begin{array}{l}\text { Fastabiqul khairat (competitive in } \\
\text { doing good deeds) }\end{array}$ & 4.27 & 85.4 & 3.92 & 78.4 \\
\hline Maslahah ummah (public interest) & 4.30 & 86.0 & 4.06 & 81.2 \\
\hline Overall Mean & 4.273 & 85.45 & 4.2 & 83.95 \\
\hline
\end{tabular}

Among these four indicators, the most significant indicator agreed by ISE stakeholders was maslahah ummah with a score of 86 percent. This was 
followed closely by both ta'awanu alal birri wattaqwa and fastabiqul khairat with 85.4 percent. Amar ma'ruf nahi munkar scored the lowest percentage in agreement as an Islamic social accountability dimension with 85 percent. On the other hand, the most significant indicator agreed by ISE management was ta'awanu alal birri wattaqwa (89\%), followed closely by amar ma'ruf nahi munkar (87.2\%), maslahah ummah (81.2\%) and fastabiqul khairat (78.4\%). It was predicted that ISE stakeholders would demand maslahah ummah as it entailed the most significant impact for stakeholders. Whereas, ISE management viewed cooperation with its stakeholders as the most important to ensure that they would be able to achieve the targeted social objectives. Therefore, it can be concluded that all four indicators were accepted by the majority of ISE stakeholders and ISE management as accountability practices for Islamic social objectives in Malaysian ISEs.

\subsection{Accountability for Islamic Economic Objectives}

Accountability for Islamic economic objectives comprises two indicators, namely: (i) involvement with Islamic funds (International Shari'ah Research Academy for Islamic Finance [ISRA], 2012); and (ii) avoidance of prohibited economic activities in Islam such as riba' (interest), gharar (uncertainty), and maysir (gambling) (Kamaruddin \& Auzair, 2019a, 2019b). Based on Table 7, 85.2 percent of ISE stakeholders and 87.2 percent of ISE management agreed that Malaysian ISEs complied with accountability practices for Islamic economic objectives.

Table 7. Accountability for Islamic Economic Objectives

\begin{tabular}{ccccc}
\hline & \multicolumn{2}{c}{$\begin{array}{c}\text { ISE Stakeholder } \\
\text { Perspective } \\
\text { Indicator }\end{array}$} & \multicolumn{2}{c}{$\begin{array}{c}\text { ISE Management } \\
\text { Perspective } \\
(\mathrm{n}=102)\end{array}$} \\
& Mean & $\%$ & Mean & $\%$ \\
\hline Involvement with Islamic funds & 4.19 & 83.8 & 4.26 & 85.2 \\
$\begin{array}{l}\text { Avoidance of prohibited economic } \\
\text { activities in Islam }\end{array}$ & 4.33 & 86.6 & 4.46 & 89.2 \\
\multicolumn{1}{c}{ Overall Mean } & 4.26 & 85.2 & 4.36 & 87.2 \\
\hline
\end{tabular}

Between the two indicators, the most significant indicator agreed by ISE stakeholders was avoidance of prohibited economic activities in Islam (86.6\%) 
followed by involvement with Islamic funds (83.8\%). Similarly, the most significant indicator agreed by ISE management was avoidance of prohibited economic activities in Islam (89.2\%) followed by involvement with Islamic funds $(85.2 \%)$.

Therefore, it can be concluded that both indicators were accepted by the majority of ISE stakeholders and ISE management as accountability practices for Islamic economic objectives in Malaysian ISEs.

\subsection{Accountability for other Islamic Principles and Values}

Accountability for other Islamic principles and values comprises five indicators, as follows: (i) 'adala (social justice); (ii) ihsan (benevolence); (iii) amanah (trust); (iv) ikhlas (sincerity); and (v) rahmah (compassion) (Muhamed et al., 2016; Kamaruddin \& Auzair, 2019a, 2019b). Based on Table 8, 85.8 percent of ISE stakeholders and 85.68 percent of ISE management agreed that Malaysian ISEs complied with accountability practices for other Islamic principles and values.

Table 8. Accountability for other Islamic Principles and Values

\begin{tabular}{lcccc}
\hline \multicolumn{1}{c}{ Indicator } & \multicolumn{2}{c}{$\begin{array}{c}\text { ISE Stakeholder } \\
\text { Perspective } \\
(\mathrm{n}=100)\end{array}$} & \multicolumn{2}{c}{$\begin{array}{c}\text { ISE Management } \\
\text { Perspective } \\
(\mathrm{n}=102)\end{array}$} \\
& Mean & $\%$ & Mean & $\%$ \\
\hline 'adala (social justice) & 4.26 & 85.2 & 4.28 & 85.6 \\
Ihsan (benevolence) & 4.31 & 86.2 & 4.24 & 84.8 \\
Amanah (trust) & 4.32 & 86.4 & 4.31 & 86.2 \\
Ikhlas (sincerity) & 4.35 & 87.0 & 4.34 & 86.8 \\
Rahmah (compassion) & 4.21 & 84.2 & 4.25 & 85.0 \\
\multicolumn{1}{c}{ Overall Mean } & 4.29 & 85.8 & 4.29 & 85.68 \\
\hline
\end{tabular}

Among these five indicators, the most significant indicator agreed by ISE stakeholders was ikhlas with 87 percent, which was the highest score among all indicators suggested in this study. This was followed closely by amanah $(86.4 \%)$, ihsan (86.2\%), 'adala (85.2\%) and rahmah (84.2\%). Similarly, the priorities in accountability for procedures by ISE management were also ikhlas $(86.8 \%)$, followed closely by amanah (86.2\%). Despite this, the priorities which came after 
was 'adala (85.6\%), rahmah (85\%) and ihsan (84.8\%). The results indicated that ISE stakeholders and ISE management seek ikhlas and amanah as the top most important Islamic principles and values that need to be realised by Malaysian ISEs. Therefore, it can be concluded that all five indicators were accepted by the majority of ISE stakeholders and ISE management as accountability practices for other Islamic principles and values in Malaysian ISEs.

\subsection{T-Test Analysis}

Last but not least, an independent T-test analysis was conducted in order to compare agreement between ISE stakeholders and ISE management on accountability practices of Malaysian ISEs. The findings are presented in Table 9. Table 9. Accountability for other Islamic Principles and Values

\begin{tabular}{|c|c|c|c|c|}
\hline \multirow[b]{2}{*}{ Accountability Dimension } & \multicolumn{4}{|c|}{ t-Test for Equality of Means } \\
\hline & $\mathrm{t}$ & df & Sig & $\begin{array}{c}\text { Mean } \\
\text { Difference }\end{array}$ \\
\hline Accountability for Input & -6.841 & 200 & $0.000^{*}$ & -0.67113 \\
\hline Accountability for Output & -7.082 & 200 & $0.000 *$ & -0.69964 \\
\hline Accountability for Procedures & -2.645 & 200 & $0.009 *$ & -0.30211 \\
\hline $\begin{array}{l}\text { Accountability for Islamic Social } \\
\text { Objectives }\end{array}$ & 0.596 & 200 & 0.552 & 0.07397 \\
\hline $\begin{array}{l}\text { Accountability for Islamic Economic } \\
\text { Objectives }\end{array}$ & -0.841 & 200 & 0.401 & -0.10275 \\
\hline $\begin{array}{l}\text { Accountability for Other Islamic } \\
\text { Principles and values }\end{array}$ & 0.031 & 200 & 0.975 & 0.00373 \\
\hline
\end{tabular}

$* p$-value $=<0.05$, significant value

Table 9 shows that accountability for input $(\mathrm{p}=0.000)$, accountability for output $(\mathrm{p}=0.000)$ and accountability for procedures $(\mathrm{p}=0.009)$ are significantly different in practice between ISE stakeholders and ISE management perspective. In contrast, accountability for Islamic social objectives, Islamic economic objectives and other Islamic principles and values recorded no significant difference in practice between ISE stakeholders and ISE management. The accountability for other Islamic principles and values was the most agreed upon indicator with 97.5 percent for both ISE stakeholders and ISE management, that Malaysian ISEs observed this accountability practice. This was followed by accountability for Islamic social objectives and accountability for Islamic economic objectives with 55.2 percent and 40.1 percent for both ISE stakeholders 
and ISE management. Therefore, it can be concluded that there are differences in priorities for accountability and Islamic accountability practices in Malaysian ISEs for both ISE stakeholders and ISE management.

\section{Conclusion}

This study has provided significant information on the accountability practices of Malaysian ISEs from the perspectives of ISE stakeholders and ISE management. This study tested six accountability dimensions, which were: (i) accountability for input; (ii) accountability for output; (iii) accountability for procedures; (iv) accountability for Islamic social objectives; (v) accountability for Islamic economic objectives; and (vi) accountability for other Islamic principles and values. All indicators that measured accountability dimensions in Malaysian ISEs were agreed by the majority of ISE stakeholders and ISE management.

Among these six accountability dimensions, the most significant for ISE stakeholders was accountability for other Islamic principles and values (85.8\%), followed closely by accountability for Islamic social objectives (85.45\%), accountability for Islamic economic objectives $(85.2 \%)$, accountability for procedures $(81.85 \%)$, accountability for output $(73.03 \%)$ and accountability for input $(72.95 \%)$. On the other hand, the most significant accountability dimension for ISE management was accountability for procedures $(87.85 \%)$, followed closely by accountability for Islamic social objectives (87.2\%), accountability for output (86.97\%), accountability for input (86.4\%), accountability for other Islamic principles and values $(85.68 \%)$ and accountability for Islamic economic objectives $(83.95 \%)$.

In addition, the t-test results showed differences in the levels of agreement between accountability and Islamic accountability practices in Malaysian ISEs from the perspective of ISE stakeholders and ISE management. There was a significant difference in the level of agreement on accountability for input and output, and accountability for procedures by Malaysian ISEs, whereas accountability for Islamic social objectives, accountability for Islamic economic objectives and accountability for other Islamic principles and values did not differ significantly between both perspectives.

The empirical findings from this study can be used by Malaysian ISEs to enhance their accountability practices in order to gain their stakeholders' trust, especially for sustainability concerns. The difference in priorities for accountability indicators also provides a basis for which Malaysian ISEs can understand and manage its numerous and diverse groups of stakeholders and thus achieve more efficient value creation for its stakeholders in the future.

The following are some limitations of this study and suggestions for future research. As this study selected CLBGs as ISE management to serve as 
respondents, other types of organisations such as societies, associations and foundations which may have different views on accountability could not be considered. Therefore, other types of ISEs could be explored in future for their views on ISE accountability practices. Apart from this, the sample size of ISE stakeholders employed was relatively small; a larger sample for each stakeholder group (upward, downward, inward and horizontal accountability) could produce different views on ISE accountability practices. Besides, comparisons between these stakeholder groups could also reveal different interests across stakeholder groups. Furthermore, due to differences in agreement between ISE stakeholders and ISE management on accountability practices for input, output and procedures, future research could be conducted to investigate the reasons for such differences in views. Last but not least, factors that enhance ISE accountability practices could be investigated to improve the performance of ISEs in the future.

\section{Acknowledgements}

The authors would like to thank Universiti Kebangsaan Malaysia for the financial assistance from the research grant, Governing the Islamic Social Enterprise towards Accountability (GUP-2017-101).

\section{References}

Abdul Kadir, M. A. B., \& Mhd Sarif, S. (2015). Social enterprise sustainability: An exploratory case of selected private Islamic schools in Malaysia. International Academic Research Journal of Social Science, 1(2), 255263.

Ahmad, S. F. (1988). The ethical responsibility of business: Islamic principles and implications. Journal of Objective Studies, 3(1), 23-43.

Candler, G., \& Dumont, G. (2010). A non-profit accountability framework. Canadian Public Administration, 53(2), 259-279.

Cheah, J., Amran, A., \& Yahya, S. (2019). External oriented resources and social enterprises' performance: The dominant mediating roles of formal business planning. Journal of Cleaner Production, 236, 117693.

Cooper, S. M., \& Owen, D. L. (2007). Corporate social reporting and stakeholder accountability: The missing link. Accounting, Organizations and Society, 32(7), 649-667.

Defourny, J., \& Nyssens, M. (2008). Social enterprise in Europe: Recent trends and developments. Social Enterprise Journal, 4(3), 202-228. 
Dhanani, A., \& Connolly, C. (2012). Discharging not-for-profit accountability: UK charities and public discourse. Accounting, Auditing \& Accountability Journal, 25(7), 1140-1169.

DOSM. (2016). Current population estimates, Malaysia, 2014-2016. The office of chief statistician Malaysia. Department of Statistics (DOS) Malaysia. Retrived from https:/www.dosm.gov.my

Ebrahim, A. (2003). Making sense of accountability: Conceptual perspectives for Northern and Southern nonprofits. Nonprofit Management and Leadership, 14(2), 191-212.

Ebrahim, A., Battilana, J., \& Mair, J. (2014). The governance of social enterprises: Mission drift and accountability challenges in hybrid organizations. Research in Organizational Behavior, 34, 81-100.

Hati, S. R. H., \& Idris, A. (2014). Antecedents of customers' intention to support Islamic social enterprises in Indonesia. Asia Pacific Journal of Marketing and Logistics, 26(5), 707-737.

Hyndman, N., \& McMahon, D. (2011). The hand of government in shaping accounting and reporting in the UK Charity Sector. Public Money \& Management, 31(3), 167-174.

Hynes, B. (2009). Growing the social enterprise-issues and challenges. Social Enterprise Journal, 5(2), 114-125.

ISRA. (2012). Islamic financial system: Principles \& operations. Kuala Lumpur: International Shari'ah Research Academy for Islamic Finance (ISRA).

Izaguirre, G. A. G. (2015). Social enterprises: examining accountability for social and financial performance (Unpublished master's dissertation). Queensland University of Technology, Australia.

Kamaruddin, M. I. H., \& Auzair, S. M. (2018). Classification of Islamic social enterprise in Malaysia based on economic sectors. Management and Accounting Review, 17(2), 17-42.

Kamaruddin, M. I. H., \& Auzair, S. M. (2019a). Conceptualizing Islamic social enterprise (ISE) from Islamic perspective. International Journal of Management, Accounting and Economics, 6(4), 368-381.

Kamaruddin, M. I. H., \& Auzair, S. M. (2019b). Integrated Islamic financial accountability model for Islamic social enterprise (ISE). The Journal of Muamalat and Islamic Finance Research, 16(1), 17-36.

Mohiuddin, M. F. (2017). Islamic social enterprises in Bangladesh: Conceptual and institutional challenges. Cogent Business \& Management, 4(1), 1305674.

Muhamed, N. A., Ramli, N. M., Shukor, S. A., \& Kamaruddin, M. I. H. (2016). Governing the Islamic social enterprise (ISE). In N. A. Muhamed (Ed.), Critical readings in Islamic social finance. Vol. 2, YTI Lecture Series (pp. 205-227). Negeri Sembilan: USIM Press. 
Muhamed, N. A., Kamaruddin, M. I. H., \& Nasrudin, N. S. M. (2018). Positioning Islamic social enterprise (ISE). Journal of Emerging Economies and Islamic Research, 6(3), 28-38.

O’Dwyer, B., \& Unerman, J. (2008). The paradox of greater NGO accountability: A case study of amnesty Ireland. Accounting, Organizations and Society, 33(7), 801-824.

Ramli, N. M., Muhamed, N. A., \& Kamaruddin, M. I. H. (2016). The financial management perspectives of Islamic social enterprise. In Nurul Aini Muhamed \& M. Obaidullah (Eds.), Critical readings in Islamic social finance. Vol. 2, YTI Lecture Series (pp. 229-254). Negeri Sembilan: USIM Press.

Sarman, S. R., Zainon, S., Atan, R, Bakar, Z. A., Yoke, S. K., Ahmad, S. A., \& Shaari, N. H. M. (2015). The web-based accountability practices in social enterprises: Validating the stakeholder theory. Procedia Economics and Finance, 31, 243-250.

Sekaran, U., \& Bougie, R. J. (2016). Research methods for business: A skill building approach (7th ed.). John Wiley \& Sons.

Wronka-Pospiech, M. (2016). The identification of skills and competencies for effective management in social enterprises. A managerial perspective. Management, 20(1), 40-57.

Yuesti, A., Novitasari, L. G., \& Rustiarini, N. W. (2016). Accountability of non-government organization from the perspective of stakeholder theory. International Journal of Accounting and Taxation, 4(2), 98-119.

Zainon, S., Ahmad, S. A., Atan, R., Wah, Y. B., Bakar, Z. A., \& Sarman, S. R. (2014). Legitimacy and sustainability of social enterprise: Governance and accountability. Procedia-Social and Behavioral Sciences, 145, 152157. 